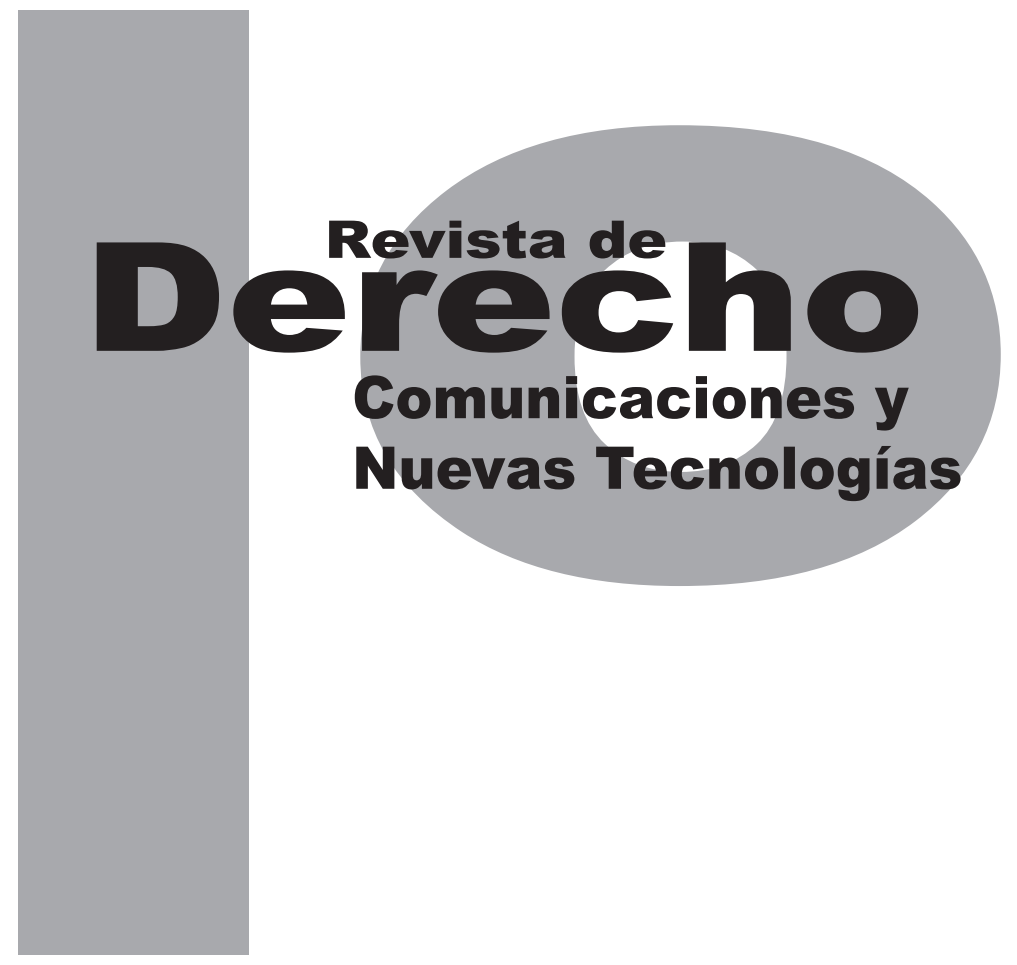

\title{
THE USE OF THE DMCA TO STIFLE FREE EXPRESSION
}

\author{
EDUARDO BERTONI \\ SOPHIA SADINSKY
}

Artículo de reflexión

DOI: http://dx.doi.org/10.15425/redecom.13.2015.01

\author{
Universidad de los Andes \\ Facultad de Derecho
}

Revista de Derecho, Comunicaciones y Nuevas Tecnologías

No.13, Enero - Junio de 2015. ISSN 1909-7786 


\section{The use of the DMCA to stifle free expression}

Abstract

This paper examines the misuse of the Digital Millennium Copyright Act (DMCA) to censor political and other forms of speech online, with a particular focus on its impact in Latin America. It reviews the characteristics and scope of the DMCA and highlights several cases in North and South America in which the legislation has been used to remove online content. The paper briefly outlines the international and regional standards that govern freedom of expression and how DMCA takedowns violate these norms. Finally, it presents existing proposals to mitigate the use of the DMCA to censor protected speech and offers additional recommendations.

Keywords: Digital Millennium Copyright Act (DMCA), freedom of expression, censorship, copyright, Latin America, Internet, intermediary liability, human rights

\section{El uso de la DMCA para restringir la libertad de expresión}

\section{Resumen}

Este documento examina el mal uso de la ley Digital Millennium Copyright Act (DMCA, según su sigla en inglés) para censurar el discurso político y otras expresiones en línea, con atención especial a su impacto en América Latina. Se revisan las características y el alcance de la DMCA y se resaltan diversos casos en América del Norte y América del Sur en los cuales se ha usado esta legislación para eliminar contenido en línea. El documento resume brevemente los estándares internacionales y regionales que regulan la libertad de expresión y cómo el uso abusivo de la DMCA viola dichas normas. Finalmente, presenta las propuestas vigentes que buscan mitigar el uso de la DMCA para censurar la expresión protegida y ofrece recomendaciones adicionales.

Palabras clave: Libertad de expresión, censura, derechos de autor, América Latina, responsabilidad de los intermediarios, derechos humanos

\section{O uso da DMCA para restringir a liberdade de expressão}

Resumo

Este documento examina o mau uso da lei Digital Millennium Copyright Act (DMCA, segundo sua sigla em inglês) para censurar o discurso político e outras expressões em linha, com atenção especial a seu impacto na América Latina. Revisam-se as características e o alcance da DMCA e se ressaltam diversos casos na América do Norte e na América do Sul nos quais se tem usado esta legislação para eliminar conteúdo online. 0 documento resume brevemente os padrões internacionais e regionais que regulam a liberdade de expressão e como o uso abusivo da DMCA viola ditas normas. Finalmente, apresenta as propostas vigentes que buscam mitigar o uso da DMCA para censurar a expressão protegida e oferece recomendações adicionais.

Palavras-chave: Liberdade de expressão, censura, direitos de autor, América Latina, responsabilidade dos intermediários, direitos humanos. 


\title{
The use of the DMCA to stifle free expression*
}

\author{
Eduardo Bertoni ${ }^{* *}$ \\ Sophia Sadinsky***
}

\section{SUMARIO}

Introduction - I. THE DMCA: OVERVIEW AND MISUSE OF COPYRIGHT GUIDELINES - II. SAMPLING OF CASES IN NORTH AMERICA - III. THE DMCA IN LATIN AMERICA: REGIONAL CASES AND CONTEXT - IV. INTERNATIONAL STANDARDS ON CENSORSHIP AND ONLINE FREEDOM OF EXPRESSION - A. United Nations standards - B. Inter-American human rights system - C. European human rights system - V. THE FUTURE OF THE DMCA AND FREE SPEECH: RECOMMENDATIONS AND WAYS FORWARD - VI. CONCLUSIONS - Bibliography

* How to cite this article: Bertoni, E. and Sadinsky, S. (Junio, 2015) The use of the DMCA to stifle free expression. Revista de Derecho, Comunicaciones y Nuevas Tecnologías, 13. Universidad de los Andes (Colombia).

** Prof. Eduardo Bertoni (Phd) currently teaches at Palermo University School of Law, Argentina and is the Director of the Center for Studies on Freedom of Expression and Access to Information (CELE) at the university. He was the Special Rapporteur for Freedom of Expression of the Inter-American Commission on Human Rights at the Organization of American States (2002-2005). Teaching Fellow at the Human Rights Institute at Columbia University School of Law (2001). Reagan-Fascell Democracy Fellow (2012-13) at the National Endowment for Democracy (NED). Member of advisory boards of the Human Rights Initiative (Open Society Foundations), the Media Legal Defence Initiative, the Freedom of Information Advocates Network (FOIAnet), among others. He has published several opinion pieces on democracy and human rights in leading newspapers in the Americas and has written several publications on the right to freedom of expression, judicial reforms, international criminal law and human rights and the Internet. Email: eberto2@palermo.edu

*** Sophia Sadinsky graduated from Wesleyan University (2011), with a double major in the interdisciplinary Science in Society Program, concentrating in psychology and feminist, gender, and sexuality studies, and French Studies. Sophia has worked with several nonprofit human rights and public policy organizations, including MADRE, the Sexuality Information and Education Council of the United States (SIECUS), the Drum Major Institute for Public Policy, and The Center for HIV Law and Policy. For the past two years, she has lived in Buenos Aires, Argentina, where she was working with the NGO Fundación para Estudio e Investigación de la Mujer (FEIM) prior to beginning her current Princeton in Latin America fellowship with the Center for Studies on Freedom of Expression and Access to Information (CELE) and Human Rights Watch. Email: sophiasadinsky@gmail.com 
Introduction

On October 9, 2013, Ecuadorian filmmaker Pocho Álvarez discovered that one of his documentaries had been removed from his YouTube page. In its place was a message from YouTube alerting him that the video was no longer available on the grounds of copyright infringement. The documentary, "Assault on Intag," is a short expository piece on the harassment suffered by the indigenous Intag community for its resistance to mining in the region. It included less than 20 seconds of images and the voice of Ecuador's President Rafael Correa, repeating the phrase "let us see who is causing these problems," suggesting that local communities were responsible for delaying regional development. The video's removal was based on the claim that Álvarez had violated copyright rules by using footage of President Correa taken from his weekly national broadcast. ${ }^{2}$

The copyright guidelines in question were those established under the Digital Millennium Copyright Act (DMCA), which the United States Congress passed in 1998 to combat online infringement. The Act includes an expedited "notice and takedown" system that allows rights holders to request that online service providers, such as social media websites, remove content or links for copyright infringement with no legal oversight. As long as companies like YouTube comply

2 Some of these events were documented in the opinion piece, "La censura en Ecuador llegó a Internet" [Censorship in Ecuador has made it to the Internet] (2014, December 12). El País. Retrieved from http:/l elpais.com/elpais/2014/12/12/opinion/1418385250_354771.html with these requests, they can avoid liability for content posted by their users.

As in the case of Álvarez, this means that the contested content is almost always removed immediately, though users may appeal the takedowns, and often do so invoking the principle of "fair use," an exception in U.S. law that permits the reproduction of copyrighted material for certain purposes, such as criticism, commentary, parody, teaching, and research. Under the counter claim process, content is typically restored within two weeks, but at that point the removals have often already taken their toll, especially in the case of political speech. The DMCA is often used to get content removed during pivotal political moments or in the midst of campaign cycles, silencing oppositional voices when they count most.

The use of the DMCA as a tool for political censorship is neither regionally nor ideologically specific. This report demonstrates how it has been applied in a range of cases around the world that are startlingly diverse in terms of their scale, substance, and the players involved. Finally, it considers viable options for preventing DMCA abuses in the future. Activists, legal experts, representatives of civil society, and online service providers themselves have proposed several approaches to address what is largely considered this insidious but unintended consequence of the DMCA. Some call for a wholesale revision of the Act, while others recommend finite changes in its application to protect users' rights to free speech. The report provides a comprehensive survey of the rights violations that occur as a re- 
sult of DMCA abuses and a measured look at the long-term benefits and potential pitfalls of the available recommendations in the field.

\section{THE DMCA: OVERVIEW AND MISUSE OF COPYRIGHT GUIDELINES}

The 1998 passage of the Digital Millennium Copyright Act signaled an effort by legislators to update U.S. copyright law in order to reflect the rapidly changing digital landscape. The Act's expedited "notice and takedown" provision intends to protect providers of online services by exempting them from potentially crippling liability; providers, such as Google or Twitter, are granted "safe harbor" from fines related to infringing content in exchange for its speedy removal, without legal action or judicial oversight.

Many Internet activists and experts agree that the DMCA has supported the swift growth of the Internet, asserting the importance of a notice and takedown system that not only protects intellectual property online but also grants service providers a level of immunity that has proved critical for online innovation. ${ }^{3}$ It is not difficult to conjure scenarios that illustrate the merit of such a system for companies and users alike; imagine the consequences for civic engagement

3 For example, see: Edwards, L. (2011). The role and responsibility of internet intermediaries in the field of copyright and related rights. Retrieved from http://www.wipo.int/export/sites/www/copyright/en/ doc/role_and_responsibility_of_the_internet_intermediaries_final. pdf ; Electronic Frontier Foundation (n.d.). Digital Millennium Copyright Act. Retrieved from https://www.eff.org/issues/dmca; Kravets, D. (2008, October 27). 10 years later, misunderstood DMCA is the law that saved the web. Wired. Retrieved from http://www.wired.com/2008/10/ ten-years-later/; Stallman, E. (2014, October 17). Exporting the DMCA. Center for Democracy \& Technology Blog. Retrieved from https://cdt. org/blog/exporting-the-dmca/; x; if users had to substantiate their ownership of content or fair use rights prior to uploading. Likewise, the free flow of content would be dramatically obstructed if a provider like YouTube had to verify content proprietorship before letting each of the billions of videos that it hosts through. The notice and takedown system has circumvented these concerns by establishing an unburdensome mechanism to protect copyright without hampering the lightening pace of digital publishing.

It has also, however, opened the door to widespread free speech violations. The ease with which takedown requests can be issued, and the incentives for companies to quickly comply with them, has left considerable room for copyright holders to abusively and repeatedly intervene for the removal of content they deem undesirable. Intermediaries, like YouTube and Facebook, are not required under the provision to review the validity of the claims prior to removing the infringing content; they immediately remove the contested material, often only double-checking the contact information of the objecting party. In addition, many service providers have some variation of a "three strike" policy, shutting down users' accounts after a certain number of takedowns. Though users frequently appeal these takedowns by citing the "fair use" principle, ${ }^{4}$

$4 \quad$ Professor and Internet expert Lawrence Lessig has highlighted the complexities of relying on "fair use" as a blanket solution for protecting non-infringing content, noting that digital technologies have changed the way content is used and related freedoms. Existing legal structures, he warns, have not caught up with the digital world, transferring enormous burden to the "fair use" principle to protect a vast range of creative works previously safeguarded as "free uses" that would not trigger copyright law. For additional information, see: Lessig, L. (2005, October 26). CC in Review: Lawrence Lessig on CC \& fair use. Retrieved from http://creativecommons.org/weblog/entry/5681. 
the restoration process takes up to two weeks, which may be a decisive delay for political events and time-sensitive activism.

\section{SAMPLING OF CASES IN NORTH AMERICA}

Abusive use of the DMCA was pervasive during the 2008 presidential elections in the United States, and both political parties felt the consequences of takedowns that limited free expression in their campaigns. In September of that year, for example, NBC issued a takedown for a satirical Obama campaign video. The viral video used archival footage of reporter Tom Brokaw announcing that Senator John McCain had "won" and was intended to encourage Obama supporters to vote. It was removed from YouTube following NBC's objections that the spot infringed on its copyrighted material, just days before an important voter registration deadline. ${ }^{5}$

The McCain camp was on the receiving end of a different broadcasting company's copyright infringement claims the following month, when CBS News filed a takedown notice in response to a video released by the McCain campaign. ${ }^{6}$ The advertisement sought to highlight sexism direc-

5 Electronic Frontier Foundation. (2008). NBC issues takedown on viral Obama ad. Retrieved from https://www.eff.org/takedowns/nbc-issuestakedown-viral-obama-ad

$6 \quad$ Electronic Frontier Foundation (2008). CBS News censors McCain ad during heated presidential campaign. Retrieved from https://www.eff. org/takedowns/cbs-news-censors-mccain-ad-during-heated-presidential-campaign ted at Sarah Palin and featured CBS news anchor Katie Couric commenting, "One of the great lessons of that campaign is the continued and accepted role of sexism in American life." ${ }^{7}$ In the original clip, which aired months before Palin entered the race, Couric was actually discussing Hillary Clinton. The McCain-Palin campaign was subject to takedowns from a range of news outlets throughout the election, including Fox News and the Christian Broadcasting Network, prompting them in October of 2008 to send a letter to YouTube detailing the "overreaching copyright claims" targeting political speech that was "clearly privileged under the fair use doctrine."

Abusive use of the DMCA to stifle political speech has continued in the United States on both sides of the aisle, and not only during campaign season. In 2009, the National Organization for Marriage, an anti-gay group that rallies against same-sex marriage, produced an advertisement in which various actors pretended to be scared of equal rights for gay couples. After another organization found and posted video footage online of the "auditions" for the ad, MSNBC's Rachel Maddow played the audition tapes on her television show, mocking the ad and criticizing its dangerous premise. The National Organization for Marriage sent a DMCA threat to YouTube claiming that the audition tapes were

7 Smith, B. (2008, September 10). CBS takes down McCain webad, suggests it's 'misleading'. Politico. Retrieved from http://www.politico.com/ blogs/bensmith/0908/CBS_takes_down_McCain_webad_suggests_ its_misleading.html

Lohmann, F.V. (2008, October 14). McCain campaign feels DMCA sting. Electronic Frontier Foundation Deeplinks Blog. Retrieved from https:// www.eff.org/deeplinks/2008/10/mccain-campaign-feels-dmca-sting 
copyrighted material, which resulted in the removal of Maddow's show from YouTube. ${ }^{9}$

Another politically charged case involved Right Wing Watch (RWW), a project of the organization People for the American Way that monitors and publicizes the activities of right-wing religious and political figures. In 2013, Gordon Klingenschmitt, a former Navy chaplain who has since been elected to the Colorado House of Representatives, filed a series of DMCA takedown notices with YouTube for clips - clearly protected under the fair use exception - from RWW's channel that highlight incendiary statements by conservative groups and individuals. Among these clips were several segments excerpted from Klingenschmitt's own show, Pray in Jesus' Name, which is also hosted on YouTube. Despite the clips' eventual restoration following counternotification filings by RWW, Klingenschmitt's abusive takedown crusade resulted in RWW'S account being taken offline twice..$^{10}$

Though DMCA takedowns were far less widespread in the 2012 presidential campaign, the 2014 midterm elections saw multiple DMCA-based free speech violations. In October, the editorial board of the Kentucky newspaper CourierJournal interviewed Alison Lundergan Grimes, a Democratic candidate for Senate. The inter-

9 Poulsen, K. (2009, April 13). Anti-gay-rights group gets MSNBC clip pulled from YouTube. Wired. Retrieved from http://www.wired.com/2009/04/ anti-gay-rights/

10 McSherry, C. (2013, December 8). No more downtime for free speech: EFF helps People for the American Way challenge DMCA abuser. Electronic Frontier Foundation Deeplinks Blog. Retrieved from https://www. eff.org/deeplinks/2013/12/no-more-downtime-free-speech-eff-helpspeople-american-way-challenge-dmca-abuser view, which streamed live and was later posted online by a critic, included 40 seconds during which Grimes refused to admit voting for President Obama, who is not popular in her state. ${ }^{11}$ Gannett Co. Inc., a media conglomerate that owns the Courier-Journal, filed a copyright claim with YouTube and had the video of the interview promptly removed. ${ }^{12}$

The United States is not alone in using the DMCA as a mechanism for silencing political and social commentary. In 2013, the Alberta, Canada tourism bureau issued a takedown notice to remove a video produced by two comedians that satirizes Alberta travel publicity. In the clip, a few seconds of the tourism bureau's advertisement are used, juxtaposing the ad's regional nature shots with the environmental degradation underway in Alberta's oil fields. The video mocks the bureau's slogan: "Remember to Breathe." Following its release, the tourism bureau hired a law firm that also represents major oil companies in the region to file a DMCA takedown with YouTube, resulting in the video trailer's removal. ${ }^{13}$

In another case out of Canada, the Canada Post filed a takedown notice with YouTube af-

11 Bump, P. (2014, October 9). 40 painful seconds of Alison Lundergan Grimes refusing to say whether she voted for President Obama. Washington Post. Retrieved from http://www.washingtonpost. com/blogs/the-fix/wp/2014/10/09/40-painful-seconds-of-alison-lundergan-grimes-refusing-to-say-whether-she-voted-for-president-obama/

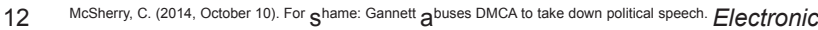
Frontier Foundation Deeplinks Blog. Retrieved from https://www.eff. org/deeplinks/2014/10/shame-gannett-abuses-dmca-take-down-political-speech

13 Stoltz, M. (2013, August 20). Using copyright to silence oil sands satire? How crude. Electronic Frontier Foundation Deeplinks Blog. Retrieved from https://www.eff.org/deeplinks/2013/08/using-copyright-silence-oilcompany-satire-how-crude 
ter union members posted a video poking fun at the company's CEO, Moya Greene. The video, entitled "The Greench," was posted in the midst of heated disputes over sick pay benefits, and adapted lyrics from the well-known Dr. Seuss song, "You're a mean one, Mr. Grinch" to parody the CEO and corporate policies. The unfounded takedown notice the company issued, which resulted in the video's removal from YouTube, claimed copyright infringement based on an altered photo of the CEO briefly shown in the video. ${ }^{14}$

\section{THE DMCA IN LATIN AMERICA: REGIONAL CASES AND CONTEXT}

Though the Digital Millennium Copyright Act is U.S. legislation, its application has been remarkably expansive. In part because the majority of the leading social media sites and search engines are U.S.-based, the DMCA has become the default tool deployed in copyright disputes in a host of countries throughout the world, including in Latin America. The Latin American country that has been home to the most widely documented use of the DMCA to censor online speech is Ecuador, though cases have also begun to crop up in other countries like Colombia and Brazil. The Ecuadorian cases have targeted a range of users and content, from documentary filmmakers chronicling the activism of indigenous groups to Twitter users posting cartoons to satirize political events.

14 Masnick, M. (2009, January 30). Once again, you don't get to use DMCA takedowns to remove any content you don't like. Techdirt. Retrieved from https://www.techdirt.com/articles/20090127/0232393546. shtml
In September 2014, for example, the administrator of a popular Facebook page found that the link to an uploaded video had been removed for copyright infringement. The video, filmed during a violent crackdown on student protesters that month, showed police abuses allegedly committed during the protests and contained clips of President Correa praising the police's actions. A week later, the video was also removed from YouTube.

Filmmaker Santiago Villa also had a documentary of his that was critical of the Correa administration stripped from the Internet in 2014, following a takedown notice based on the use of "unauthorized images" from Correa's weekly public address. Later that year, the Twitter account for Diana Amores, a translator who often shares witty tweets with her followers, was suspended on more than one occasion following several instances in which Twitter removed images she had tweeted, including multiple cartoons. The copyright claims used to get Amores' images pulled and account ultimately suspended came from EcuadorTV, the state-run television station, and Movimiento Alianza País, the country's governing party. Her copyright infractions were as innocuous as uploading a picture in which the politician featured was wearing a t-shirt with the party's logo, presumably targeted for the humorous tagline Amores tweeted with the photo.

A common thread runs through this bewildering series of DMCA takedowns: public institutions and officials hostile to criticism and parody. Ecuador has a history of muzzling free speech under Correa, who has repeatedly abused his 
legislative powers in response to dissent, often invoking criminal defamation laws to silence his opposition. Since taking office in 2007 , he has sought unwieldy prison terms and multi-million dollar damages from media outlets for libel, demonstrating zero tolerance for dissonant voices. In 2013, the Ecuadorian National Assembly passed a Communications Law that grants the government astonishing leeway to censor public information and criminally prosecute journalists. The government has also vehemently criticized the Organization of American States' Freedom of Expression Rapporteurship and led the charge in promoting measures that would seriously undermine its autonomy and effectiveness in upholding free expression.

While Ecuador currently outpaces other countries in the region with its ongoing use of the DMCA to discourage free speech, the practice is catching on elsewhere. In Colombia, the Iglesia Ministerial de Jesucristo Internacional, which is associated with the Colombian political party known as MIRA, has repeatedly sought the removal of YouTube videos that feature, for example, declarations made by the church's founder. One of the videos that YouTube blocked upon the church's request had even explicitly noted in its title that the video was a parody. ${ }^{15}$

In Brazil, the DMCA was used to remove videos critical of 2014 presidential candidate and former governor, Aécio Neves. Though the sender's

15 Fundación para la Libertad de Prensa. (2014, February 5). Iglesia de María Luisa Piraquive bloquea contenidos periodísticos en YouTube. Retrieved from http://flip.org.co/es/content/iglesia-de-mar\%C3\%ADaluisa-piraquive-bloquea-contenidos-period $\%$ C3\%ADsticos-en-youtube identity has not been confirmed, many have speculated that Neves himself was responsible for the takedowns. ${ }^{16}$

\section{INTERNATIONAL STANDARDS ON CENSORSHIP AND ONLINE FREEDOM OF EXPRESSION}

The use of the DMCA to suppress citizens' voices is not simply a regrettable interpretation of copyright law; it directly violates international standards governing the right to free expression. Each of the cases described earlier is protected according to the United Nations' guidelines, and regionally, vis-à-vis the principles set out in the Inter-American system. The European system of human rights also establishes clear parameters for the exercise of freedom of expression that are useful to consider even in cases such as these that do not fall within the purview of the European Court.

In this section, the universal and regional norms are briefly presented, along with relevant interpretations of their application. The goal is not to provide an exhaustive review of the standards governing freedom of expression or of related case law, but rather to highlight the pertinent norms and offer an abbreviated look at the interpretations that guide their application.

16 Sutton, M. (2014, December 3). Copyright law as a tool for state censorship of the Internet. Electronic Frontier Foundation Deeplinks Blog. Retrieved from https://www.eff.org/deeplinks/2014/12/copyright-lawtool-state-internet-censorship 


\section{A. United Nations Standards}

Under the United Nations system, freedom of expression is protected according to Article 19 of the Universal Declaration of Human Rights and Article 19 of the International Covenant on Civil and Political Rights (ICCPR), in addition to other free speech guarantees.

Article 19 of the Universal Declaration of Human Rights states:

Everyone has the right to freedom of opinion and expression; this right includes freedom to hold opinions without interference and to seek, receive and impart information and ideas through any media and regardless of frontiers. ${ }^{17}$

Article 19 of the ICCPR states: ${ }^{18}$

1. Everyone shall have the right to hold opinions without interference.

2. Everyone shall have the right to freedom of expression; this right shall include freedom to seek, receive and impart information and ideas of all kinds, regardless of frontiers, either orally, in writing or in print, in the form of art, or through any other media of his choice.

3. The exercise of the rights provided for in paragraph 2 of this article carries with it special duties and responsibilities. It may therefore be subject to certain restrictions, but these shall only be such as are provided by law and are necessary:

17 Universal Declaration of Human Rights, art. 19, G.A. Res. 217 (III) A U.N. Doc. A/RES/217(III) (Dec. 10, 1948).

18 International Covenant on Civil and Political Rights, art. 19(2),opened for signature Dec. 16, 1966, 999 U.N.T.S. 171 (entered into force Mar. 23, 1976) (a) For respect of the rights or reputations of others;

(b) For the protection of national security or of public order (ordre public), or of public health or morals.

In its interpretation of Article 19 of the ICCPR, General Comment No. 34 of the United Nations Human Rights Committee affirms that States parties "are required to ensure that the rights contained in article 19 of the Covenant are given effect to in the domestic law of the State," which expressly includes, "political discourse, commentary on one's own and on public affairs, canvassing, discussion of human rights, journalism, cultural and artistic expression, teaching, and religious discourse." All forms of expression are protected, covering "all forms of audio-visual as well as electronic and internet-based modes of expression."

The comment details the very limited grounds for restrictions to free expression, emphasizing that "restrictions must be 'necessary' for a legitimate purpose," and that they "must not be overbroad." It is made clear that "the value placed by the Covenant upon uninhibited expression is particularly high in the circumstances of public debate in a democratic society." The Committee concludes that the Covenant does not permit "general prohibition of expressions of an erroneous opinion or an incorrect interpretation of past events. Restrictions on the right of freedom of opinion should never be imposed." 19

19 United Nations, Human Rights Comm., General Comment No. 34: Article 19: Freedoms of Opinion and Expression, 11, U.N. Doc. CCPR/C/ GC/34 (July 21, 2011). 
Neither of the two limitative areas of restrictions applies in any of the cases described in this report. The use of the DMCA to censor online content in these cases therefore constitutes a violation of the right to freedom of expression according to the standards laid out by the United Nations.

\section{B. Inter-American Human Rights System}

Freedom of expression in the Inter-American system is principally protected by Article 4 of the American Declaration of the Rights and Duties of Man and Article 13 of the American Convention on Human Rights. ${ }^{20}$

Article 4 states: ${ }^{21}$

Every person has the right to freedom of investigation, of opinion, and of the expression and dissemination of ideas, by any medium whatsoever.

Article 13 states: ${ }^{22}$

1. Everyone has the right to freedom of thought and expression. This right includes freedom to seek, receive, and impart information and ideas of all kinds, regardless of frontiers, either orally, in writing, in print, in the form of art, or through any other medium of one's choice.

20 Although the United States has not ratified the American Convention on Human Rights, the interpretation of this pact provided by the InterAmerican Court of Human Rights has been important in deciding U.S. cases on freedom of expression.

Organization of American States, American Declaration of the Rights and Duties of Man, OEA/Ser.L.N.II.23, doc. 21, rev. 6 (1948)

Organization of American States, American Convention on Human Rights, O.A.S.T.S. No. 36, 1144 U.N.T.S. 143 (1969).
2. The exercise of the right provided for in the foregoing paragraph shall not be subject to prior censorship but shall be subject to subsequent imposition of liability, which shall be expressly established by law to the extent necessary to ensure: a. respect for the rights or reputations of others; or b. the protection of national security, public order, or public health or morals.

3. The right of expression may not be restricted by indirect methods or means, such as the abuse of government or private controls over newsprint, radio broadcasting frequencies, or equipment used in the dissemination of information, or by any other means tending to impede the communication and circulation of ideas and opinions.

4. Notwithstanding the provisions of paragraph 2 above, public entertainments may be subject by law to prior censorship for the sole purpose of regulating access to them for the moral protection of childhood and adolescence.

5. Any propaganda for war and any advocacy of national, racial, or religious hatred that constitute incitements to lawless violence or to any other similar action against any person or group of persons on any grounds including those of race, color, religion, language, or national origin shall be considered as offenses punishable by law.

The Inter-American Court of Human Rights has interpreted Article 13 in particular in numerous cases that should be taken into account when considering the standards that dictate the right to freedom of expression. ${ }^{23}$ The Special RapPractice of Journalism, Advisory Opinion OC-5/85 of 13 November 
porteur for Freedom of Expression of the InterAmerican Commission on Human Rights, in the Inter-American Legal Framework regarding the Right to Freedom of Expression ${ }^{24}$ and the Declaration of Principles on Freedom of Expression, ${ }^{25}$ has extracted from the decisions the following standards, among others:

1. Pursuant to Article 13 of the American Convention, freedom of expression is a right of every person, under equal conditions and without discrimination of any kind.

\section{Article 13 of the American Convention esta- blishes the right of every person to freedom of expression, and specifies that this right encom- passes the "freedom to seek, receive, and im-}

1985, Series A, No. 5, para. 70.; I/A Court H.R., Case of Ivcher Bronstein v. Peru. Interpretation of the Judgment of the Merits. Judgment of September 4, 2001. Series C No. 84; I/A Court H.R., Case of Herrera Ulloa v. Costa Rica. Preliminary Objections, Merits, Reparations and Costs. Judgment of July 2, 2004. Series C No. 107; I/A Court H.R., Case of Ricardo Canese v. Paraguay. Merits, Reparations and Costs. Judgment of August 31, 2004. Series C No. 111; I/A Court H.R., Case of Palamara Iribarne v. Chile. Merits, Reparations and Costs. Judgment of November 22, 2005. Series C No. 135; I/A Court H.R., Case of Claude Reyes et al. v. Chile. Merits, Reparations and Costs. Judgment of September 19, 2006. Series C No. 151; I/A Court H.R., Case of Kimel v. Argentina. Merits, Reparations and Costs. Judgment of May 2, 2008 Series C No. 177; I/A Court H.R., Case of Tristán Donoso v. Panama. Preliminary Objection, Merits, Reparations and Costs. Judgment of January 27, 2009. Series C No. 193; I/A Court H.R., Case of Ríos et al. v. Venezuela. Preliminary Objections, Merits, Reparations, and Costs. Judgment of January 28, 2009. Series C No. 194; I/A Court H.R., Case of Perozo et al. v. Venezuela. Preliminary Objections, Merits, Reparations, and Costs. Judgment of January 28, 2009. Series C No. 195; I/A Court H.R., Case of Usón Ramírez v. Venezuela. Preliminary Objection, Merits, Reparations and Costs. Judgment of November 20, 2009. Series C No. 207; I/A Court H.R., Case of Uzcátegui and et al. v. Venezuela. Merits and reparations. Judgment of September 3, 2012 .Series C No. 249; I/A Court H.R., Case of Fontevecchia y D’Amico v. Argentina. Merits, Reparations and Costs. Judgment of November 29, 2011. Series C No. 238.

24 Office of the Special Rapporteur for Freedom of Expression of the Inter American Commission of Human Rights, "The Inter-American Legal Framework regarding the Right to Freedom of Expression",OEA Ser.L/V/II, December 30, 2009.

Organization of American States, Declaration of Principles on Freedom of Expression, October 19, 2000. part information and ideas of all kinds, regardless of frontiers, either orally, in writing, in print, in the form of art, or through any other medium of one's choice." In its interpretation of the scope of the right to freedom of expression, the Declaration of Principles on Freedom of Expression issued by the Inter-American Commission on Human Rights indicates that this fundamental and inalienable right refers to human expression "in all its forms and manifestations," and that it covers the right of every person, under equal conditions, "to seek, receive and impart information and opinions freely," "by any means of communication," as well as the "right to communicate his/her views by any means and in any form." The Declaration of Principles also states expressly that every person has the right to "access to information about himself or herself or his/her assets expeditiously and not onerously, whether it be contained in databases or public or private registries," and to "update it, correct it and/or amend it" if necessary, as well as the right to "access to information held by the State."

3. In principle, all forms of speech are protected by the right to freedom of expression, independently of their content and degree of government and social acceptance. This general presumption of coverage of all expressive speech is explained by the State's primary duty of content-neutrality and, as a consequence, by the necessity to guarantee that, in principle, there are no persons, groups, ideas or means of expression excluded a priori from public debate.

4. Particularly important is the rule according to which freedom of expression must be guaranteed not only with regard to the dissemination of ideas and information that are received fa- 
vorably or considered inoffensive or indifferent but also in cases of speech that is offensive, shocking, unsettling, unpleasant or disturbing to the State or to any segment of the population. This is required by the pluralism, tolerance and spirit of openness without which a democratic society cannot exist. In this vein, the Commission has pointed out the special importance of protecting freedom of expression "as regards minority views, including those that offend, shock or disturb the majority," and it has emphasized that restrictions to freedom of expression "must not "perpetuate prejudice or promote intolerance."”

5. Prior censorship, direct or indirect interference in or pressure exerted upon any expression, opinion or information transmitted through any means of oral, written, artistic, visual or electronic communication must be prohibited by law. Restrictions to the free circulation of ideas and opinions, as well as the arbitrary imposition of information and the imposition of obstacles to the free flow of information violate the right to freedom of expression.

6. As it has been interpreted in the case law of the Inter-American system, Article 13.2 of the Convention requires that the following three conditions be met in order for a limitation to freedom of expression to be admissible: (1) the limitation must have been defined in a precise and clear manner by a law, in the formal and material sense; (2) the limitation must serve compelling objectives authorized by the Convention; and (3) the limitation must be necessary in a democratic society to serve the compelling objectives pursued, strictly proportionate to the objective pursued, and appropriate to serve said compelling objective.
The Inter-American Court of Human Rights has also issued decisions that prohibit prior censorship. In a 2001 case concerning a violation of Article 13 of the American Convention on Human Rights, the I.A. Court H.R. analyzed the arguments presented in Advisory Opinion 5 (OC-5) on freedom of expression. The Court first addressed the two dimensions of freedom of expression and insisted on the "democratic standard." What was new in this judgment was the interpretation of the concept of prior censorship in the Convention. The Court held that "Article 13(4) of the Convention establishes an exception to prior censorship, since it allows it in the case of public entertainment, but only in order to regulate access for the moral protection of children and adolescents. In all other cases, any preventive measure implies the impairment of freedom of thought and expression." 26

None of the cases in which the DMCA was invoked to remove users' content online meets these conditions in order for their censorship to be admissible. The characteristics of the cases, both in terms of their content and the necessary conditions for limitations, therefore render them protected speech according to the Inter-American standards.

\section{European Human Rights System}

The right to freedom of expression and information is guaranteed by Article 10 of the European

26 Bertoni, E. (2009). The Inter-American Court of Human Rights and the European Court of Human Rights: A dialogue on freedom of expression standards. European Human Rights Law Review, 3, 332-353. Emphasis is not in the original decision of the Court. 
Convention for the Protection of Human Rights and Fundamental Freedoms.

Article 10 states: $^{27}$

1. Everyone has the right to freedom of expression. This right shall include freedom to hold opinions and to receive and impart information and ideas without interference by public authority and regardless of frontiers. This article shall not prevent States from requiring the licensing of broadcasting, television or cinema enterprises.

2. The exercise of these freedoms, since it carries with it duties and responsibilities, may be subject to such formalities, conditions, restrictions or penalties as are prescribed by law and are necessary in a democratic society, in the interests of national security, territorial integrity or public safety, for the prevention of disorder or crime, for the protection of health or morals, for the protection of the reputation or rights of others, for preventing the disclosure of information received in confidence, or for maintaining the authority and impartiality of the judiciary.

While the Convention details circumstances under which the exercise of this right, "may be subject to such formalities, conditions, restrictions or penalties as are prescribed by law and are necessary in a democratic society," it "substantially reduces the possibility of interference with the right to express, receive and impart information and ideas. Interferences by public authorities are only allowed under the strict conditions

27 Council of Europe, European Convention for the Protection of Human Rights and Fundamental Freedoms, as amended by Protocols Nos. 11 and 14, 4 November 1950, ETS 5 , that any restriction or sanction must be "prescribed by law,' must have a 'legitimate aim' and finally and most decisively, must be "necessary in a democratic society." "28 Freedom of political debate in particular is considered by the European Court of Human Rights "to be at the very core of the concept of a democratic society." Given the importance of free speech within a democracy, "very strong reasons will be required to justify restrictions on political speech." 29

As noted by Professor Dirk Voorhoof, "The recognition by the European Court of a horizontal effect of Article 10 and of the positive obligations for member States to protect the right to freedom of expression has further extended the scope of the right to freedom of expression in Europe." 30

The types of speech captured in the cases described, though not within the jurisdiction of the European Court, comply with the standards detailed in the European Convention. ${ }^{31}$ The DMCA takedowns that were issued do not fulfill the

28 Voorhoof, D. (2014). The right to freedom of expression and information under the European Human Rights System: Towards a more transparent democratic society. Retrieved from http://cadmus.eui.eu/ bitstream/handle/1814/29871/RSCAS_2014_12.pdf?sequence=1

Leach, P. (2011). Taking a case to the European Court of Human Rights. New York: Oxford.

30 Voorhoof, D. (2014). The right to freedom of expression and information under the European Human Rights System: Towards a more transparent democratic society. Retrieved from http://cadmus.eui.eu/ bitstream/handle/1814/29871/RSCAS_2014_12.pdf?sequence=1

31 From the early stages (Advisory Opinion OC-5) to the most recent cases decided by the Inter-American Court, the impact of the European Court of Human Rights jurisprudence has been significant. See: Bertoni, E. (2009). The Inter-American Court of Human Rights and the European Court of Human Rights: A dialogue on freedom of expression standards. European Human Rights Law Review, 3, 332-353. 
strict conditions required to interfere in the right to free expression.

\section{THE FUTURE OF THE DMCA AND FREE SPEECH: RECOMMENDATIONS AND WAYS FORWARD}

Most Internet activists and scholars agree ${ }^{32}$ that without the DMCA's takedown provision, many online service providers would be unable to host and transmit user-generated content for fear of copyright liability. ${ }^{33}$ They also concede, however, that the Act has been chronically misused to disable access to content that is unequivocally protected under international and regional freedom of expression standards. The question, then, is how to reconcile an imperfect but necessary piece of legislation like the DMCA with the violation of core democratic principles it permits.

The United Nations Educational, Scientific and Cultural Organization (UNESCO) notes that much of the criticism aimed at the DMCA stems from the fact that it is easy to abuse. They observe that the DMCA “facilitates self-censorship by placing the intermediary in a quasi-judicial po-

32 Samuel, J. (2011, February 11). DMCA copyright policies: Staying in the safe harbors while protecting your users. Electronic Frontier Foundation Deeplinks Blog. Retrieved from https://www.eff.org/deeplinks/2011/01/dmca-copyright-policies-staying-safe-harbors-while

33 The DMCA, specifically a portion of it called the "Online Copyright Infringement

Liability Limitation Act," Section 512, provides a safe harbor for intermediaries, which immunizes them under many circumstances from copyright liability. For additional information on safe harbors and the application of liability under the DMCA, see: Boyle, J., \& Jenkins, J. (2014). Intellectual property: Law \& the

information society - cases and materials. sition responsible for evaluating the legality of content." ${ }^{34}$ Addressing the improper use of the DMCA therefore entails careful consideration of intermediary responsibility: the liability of Internet service providers, search engines, social networks, and other information hosts for user content. In the face of a stream of takedowns based on flimsy or nonexistent copyright claims, it is tempting to charge that the burden of responsibility lies with these online middlemen. One approach would then be to insist that service providers treat claims with more care; upon receipt of each takedown request, providers could assess the claim in terms of fair use and honor or dismiss the request accordingly. But evaluating copyright infringement claims on a case-by-case basis would be a mammoth undertaking, and undoubtedly would affect providers' capacity to host and transmit a diversity of content at their current pace.

The Electronic Frontier Foundation (EFF), a digital rights non-profit, supports the development of a "fair repeat infringer policy," 35 This multi-pronged approach is decidedly more usercentric than the current process. It suggests promptly notifying users when claims are made against them and giving them an ample opportunity to file counter-notices and even contact the copyright owners. EFF, joining the calls of others who have identified flaws in the existing notice and takedown system, recommends hal-

34 Bar, A., Hickok, E., Lim, H., \& MacKinnon, R. (2014). Fostering freedom online: The role of Internet intermediaries. Retrieved from http:// unesdoc.unesco.org/images/0023/002311/231162e.pdf

35 Ibid. 
ting the practice of instant termination, instead encouraging open communication with users about infringing content so that they may respond to takedown requests and avoid the automatic suspension of their accounts. ${ }^{36}$ EFF further submits that there should be something of a "trust" policy that establishes additional protections - such as a greater number of "strikes" or a fast-tracked appeals process - for users who have no significant history of posting infringing material. These measures, EFF asserts, could empower users against abusive takedowns without placing undue burden on online intermediaries.

The Global Network on Copyright Users' Rights, on the other hand, advises a more flexible approach to copyright policy itself. They introduced a Model Flexible Copyright Exception that could be adapted to most copyright laws, which proposes certain exceptions and additional guidance for copyright interpretation and implementation. Its core provision reads:

In addition to uses specifically authorized by law, any use that promotes general economic, social and cultural objectives is not infringing if its character and extent is appropriate to its purposes and does not unduly prejudice the legitimate interests of the copyright owner, ta-

36 For example, Professor Dawn Nunziato notes that the DMCA notice and takedown system provides copyright owners with considerable leeway in policing the use of their content. She asserts that the existing provision "enables a copyright owner to secure the equivalent of a temporary restraining order - a court order mandating that the allegedly infringing content be removed -- but without benefit of judicial process." Nunziato, D. C. (2011). Keeping the Internet free in the Americas. Retrieved from http://www.palermo.edu/cele/pdf/english/Internet-Free-ofCensorship/01-Keeping_Interent_free_Dawn\%20Nunziato.pdf king account of the legitimate interests of creators, users, third parties and the public. ${ }^{37}$

The Network thereby zeroes in on the DMCA itself, seeking to expand its parameters rather than simply alter its application. The model exception reflects recognition of the need to reimagine the implications of copyright in the digital age, and explicitly take stock of public and user interests.

In 2013, the freedom of expression non-profit ARTICLE 19 joined other groups in devising the "Right to Share Principles," aimed at balancing the right to freedom of expression and copyright integrity. Some central aspects of the recommendations include decriminalizing non-commercial copyright infringement; no website blocking without a court order; measures for promoting access to knowledge and culture; and transparency and human rights assessments of trade treaties dealing with copyright protection. ${ }^{38}$ Their recommendations offer best practices for dealing with copyright issues across borders, prioritizing the right to free expression and access to cultural goods. ${ }^{39}$ Some groups have proposed more extreme measures to deter abusive takedowns under

37 American University Washington College of Law. (2012). Model flexible copyright exception. Retrieved from http://infojustice.org/wp-content/uploads/2012/12/Model-Flexible-Copyright-Exception-Version4.0.pdf

38 Guillemin, G. (2014, January 17). Copyright week: Why the right to share principles matter in the digital age. Retrieved from http://www. article19.org/join-the-debate.php/132/view/

39 Article 19. (2013). The right to share: Principles on freedom of expression and copyright in the digital age. Retrieved from http://www. article19.org/data/files/medialibrary/3716/13-04-23-right-to-share-en. pdf 
the DMCA. One legal expert proposes targeting a different player altogether: the filer of the copyright infringement claims. She points out that Congress provides a mechanism to discourage improper takedowns in the form of a misrepresentation claim, which can be filed for misrepresenting that posted content is infringing. If users who have been unfairly subject to takedowns lodge these with greater frequency, they could potentially curb the misuse of the DMCA to suppress online expression by dissuading copyright owners or their representatives from filing improper claims. ${ }^{40}$

\section{CONCLUSIONS}

While each of these recommendations proposes important steps towards minimizing abusive copyright infringement claims, none entirely resolves the issue of balancing the burden between online service providers and users. Any scenario in which the DMCA is the reigning arbiter for digital content entails shared responsibility between citizens and companies; online intermediaries cannot reasonably be tasked with combing through each individual takedown request, just as lay people should not be expected to repeatedly defend their right to generate and upload non-infringing content.

Perhaps an independent third party, such as an international advisory group, could help negotiate this tricky territory by providing neutral

40 Loren, L. P. (2011). Deterring abuse of the copyright takedown regime by taking misrepresentation claims seriously. Retrieved from http:// wakeforestlawreview.com/2011/11/deterring-abuse-of-the-copyrighttakedown-regime-by-taking-misrepresentation-claims-seriously/ guidance to Internet companies on copyright procedures. This would help relieve some of the burden from providers, while simultaneously demonstrating the technology sector's desire to act as part of the solution to online free speech violations. Striking the right balance between service providers and users nonetheless calls for willingness on both sides to invest in defending the right to freedom of expression. Online services providers, including Google, YouTube, Facebook, Twitter, and other hosts, should reconsider their existing protocol with this principle in mind, soliciting feedback from users and updating their policies to ensure that the DMCA continues to enable innovation without stifling speech.

\section{Bibliography}

American University Washington College of Law. (2012). Model flexible copyright exception. Retrieved from http://infojustice.org/wpcontent/uploads/2012/12/Model-FlexibleCopyright-Exception-Version-4.0.pdf

Article 19. (2013). The right to share: Principles on freedom of expression and copyright in the digital age. Retrieved from http://www.article19.org/data/files/medialibrary/3716/1304-23-right-to-share-en.pdf

Bar, A., Hickok, E., Lim, H., \& MacKinnon, R. (2014). Fostering freedom online: The role of Internet intermediaries. Retrieved from http://unesdoc.unesco.org/ images/0023/002311/231162e.pdf 
Bertoni, E. (2009). The Inter-American Court of Human Rights and the European Court of Human Rights: A dialogue on freedom of expression standards. European Human Rights Law Review, 3, 332-353.

Bertoni, E., \& Vivanco, J.M. (2014, December 12). La censura en Ecuador llegó a Internet. El País. Retrieved from http:// elpais.com/elpais/2014/12/12/opinion/1418385250_354771.html

Boyle, J., \& Jenkins, J. (2014). Intellectual property: Law \& the information society - cases and materials.

Bump, P. (2014, October 9). 40 painful seconds of Alison Lundergan Grimes refusing to say whether she voted for President Obama. Washington Post. Retrieved from http:// www.washingtonpost.com/blogs/the-fix/ wp/2014/10/09/40-painful-seconds-ofalison-lundergan-grimes-refusing-to-saywhether-she-voted-for-president-obama/

Compulsory Membership in an Association Prescribed by Law for the Practice of Journalism, Advisory Opinion OC-5/85 of 13 November 1985, Series A, No. 5, para. 70.

Council of Europe, European Convention for the Protection of Human Rights and Fundamental Freedoms, as amended by Protocols Nos. 11 and 14, 4 November 1950, ETS 5

Edwards, L. (2011). The role and responsibility of internet intermediaries in the field of co- pyright and related rights. Retrieved from http://www.wipo.int/export/sites/www/copyright/en/doc/role_and_responsibility_of_ the_internet_intermediaries_final.pdf

Electronic Frontier Foundation (n.d.). Digital Millennium Copyright Act. Retrieved from https://www.eff.org/issues/dmca

Electronic Frontier Foundation. (2008). NBC issues takedown on viral Obama ad. Retrieved from https://www.eff.org/takedowns/nbcissues-takedown-viral-obama-ad

Electronic Frontier Foundation (2008). CBS News censors McCain ad during heated presidential campaign. Retrieved from https:// www.eff.org/takedowns/cbs-news-censorsmccain-ad-during-heated-presidential-campaign

Fundación para la Libertad de Prensa. (2014, February 5). Iglesia de María Luisa Piraquive bloquea contenidos periodísticos en YouTube. Retrieved from http://flip.org.co/es/content/ iglesia-de-mar\%C3\%ADa-luisa-piraquive-bloquea-contenidos-period\%C3\%ADsticos-enyoutube

Guillemin, G. (2014, January 17). Copyright week: Why the right to share principles matter in the digital age. Retrieved from http:// www.article19.org/join-the-debate.php/132/ view/

I/A Court H.R., Case of Ivcher Bronstein v. Peru. Interpretation of the Judgment of the Merits. 
Judgment of September 4, 2001. Series C No. 84.

I/A Court H.R., Case of Herrera Ulloa v. Costa Rica. Preliminary Objections, Merits, Reparations and Costs. Judgment of July 2, 2004. Series C No. 107.

I/A Court H.R., Case of Ricardo Canese v. Paraguay. Merits, Reparations and Costs. Judgment of August 31, 2004. Series C No. 111.

I/A Court H.R., Case of Palamara Iribarne v. Chile. Merits, Reparations and Costs. Judgment of November 22, 2005. Series C No. 135.

I/A Court H.R., Case of Claude Reyes et al. v. Chile. Merits, Reparations and Costs. Judgment of September 19, 2006. Series C No. 151.

I/A Court H.R., Case of Kimel v. Argentina. Merits, Reparations and Costs. Judgment of May 2, 2008 Series C No. 177.

I/A Court H.R., Case of Tristán Donoso v. Panama. Preliminary Objection, Merits, Reparations and Costs. Judgment of January 27, 2009. Series C No. 193.

I/A Court H.R., Case of Ríos et al. v. Venezuela. Preliminary Objections, Merits, Reparations, and Costs. Judgment of January 28, 2009. Series C No. 194.

I/A Court H.R., Case of Perozo et al. v. Venezuela. Preliminary Objections, Merits, Reparations, and Costs. Judgment of January 28, 2009. Series C No. 195.
I/A Court H.R., Case of Usón Ramírez v. Venezuela. Preliminary Objection, Merits, Reparations and Costs. Judgment of November 20, 2009. Series C No. 207.

I/A Court H.R., Case of Uzcátegui and et al. v. Venezuela. Merits and reparations. Judgment of September 3, 2012 .Series C No. 249.

I/A Court H.R., Case of Fontevecchia y D`Amico v. Argentina. Merits, Reparations and Costs. Judgment of November 29, 2011. Series C No. 238.

International Covenant on Civil and Political Rights, art. 19(2),opened for signature Dec. 16, 1966, 999 U.N.T.S. 171 (entered into force Mar. 23, 1976).

Kravets, D. (2008, October 27). 10 years later, misunderstood DMCA is the law that saved the web. Wired. Retrieved from http://www. wired.com/2008/10/ten-years-later/

Leach, P. (2011). Taking a case to the European Court of Human Rights. New York: Oxford.

Lessig, L. (2005, October 26). CC in Review: Lawrence Lessig on CC \& fair use. Retrieved from http://creativecommons.org/weblog/ entry/5681

Lohmann, F.V. (2008, October 14). McCain campaign feels DMCA sting. Electronic Frontier Foundation Deeplinks Blog. Retrieved from https://www.eff.org/deeplinks/2008/10/ mccain-campaign-feels-dmca-sting 
Loren, L. P. (2011). Deterring abuse of the copyright takedown regime by taking misrepresentation claims seriously. Retrieved from http://wakeforestlawreview.com/2011/11/ deterring-abuse-of-the-copyright-takedownregime-by-taking-misrepresentation-claimsseriously/

Masnick, M. (2009, January 30). Once again, you don't get to use DMCA takedowns to remove any content you don't like. Techdirt. Retrieved from https://www.techdirt.com/articles/20090127/0232393546.shtml

McSherry, C. (2013, December 8). No more downtime for free speech: EFF helps People for the American Way challenge DMCA abuser. Electronic Frontier Foundation Deeplinks Blog. Retrieved from https://www.eff. org/deeplinks/2013/12/no-more-downtimefree-speech-eff-helps-people-american-waychallenge-dmca-abuser

McSherry, C. (2014, October 10). For shame: Gannett abuses DMCA to take down political speech. Electronic Frontier Foundation Deeplinks Blog. Retrieved from https://www. eff.org/deeplinks/2014/10/shame-gannettabuses-dmca-take-down-political-speech

Nunziato, D. C. (2011). Keeping the Internet free in the Americas. Retrieved from http://www. palermo.edu/cele/pdf/english/InternetFree-of-Censorship/01-Keeping_Interent_ free_Dawn\%20Nunziato.pdf
Office of the Special Rapporteur for Freedom of Expression of the Inter American Commission of Human Rights, "The Inter-American Legal Framework regarding the Right to Freedom of Expression",OEA Ser.L/V/II, December 30, 2009.

Organization of American States, American Declaration of the Rights and Duties of Man, OEA/Ser.L./V.II.23, doc. 21, rev. 6 (1948).

Organization of American States, American Convention on Human Rights, O.A.S.T.S. No. 36, 1144 U.N.T.S. 143 (1969).

Organization of American States, Declaration of Principles on Freedom of Expression, October 19, 2000.

Poulsen, K. (2009, April 13). Anti-gay-rights group gets MSNBC clip pulled from YouTube. Wired. Retrieved from http://www. wired. com/2009/04/anti-gay-rights/

Samuel, J. (2011, February 11). DMCA copyright policies: Staying in the safe harbors while protecting your users. Electronic Frontier Foundation Deeplinks Blog. Retrieved from https://www.eff.org/deeplinks/2011/01/ dmca-copyright-policies-staying-safe-harborswhile

Smith, B. (2008, September 10). CBS takes down McCain webad, suggests it's 'misleading'. Politico. Retrieved from http://www. politico.com/blogs/bensmith/0908/CBS_ takes_down_McCain_webad_suggests_its_ misleading.html 
Stallman, E. (2014, October 17). Exporting the DMCA. Center for Democracy \& Technology Blog. Retrieved from https://cdt.org/blog/ exporting-the-dmca/

Stoltz, M. (2013, August 20). Using copyright to silence oil sands satire? How crude. Electronic Frontier Foundation Deeplinks Blog. Retrieved from https://www.eff.org/deeplinks/2013/08/using-copyright-silence-oilcompany-satire-how-crude

Sutton, M. (2014, December 3). Copyright law as a tool for state censorship of the Internet. Electronic Frontier Foundation Deeplinks Blog. Retrieved from https://www.eff.org/ deeplinks/2014/12/copyright-law-tool-stateinternet-censorship
United Nations, Human Rights Comm., General Comment No. 34: Article 19: Freedoms of Opinion and Expression, पा 11, U.N. Doc. CCPR/C/GC/34 (July 21, 2011).

Universal Declaration of Human Rights, art. 19, G.A. Res. 217 (III) A, U.N. Doc. A/RES/217(III) (Dec. 10, 1948)

Voorhoof, D. (2014). The right to freedom of expression and information under the European Human Rights System: Towards a more transparent democratic society. Retrieved from http://cadmus.eui.eu/bitstream/ handle/1814/29871/RSCAS_2014_12. pdf?sequence $=1$ 